\title{
Inducible Nitric Oxide Synthase Expression Is Reduced in Cystic Fibrosis Murine and Human Airway Epithelial Cells
}

\author{
Thomas J. Kelley and Mitchell L. Drumm‡ \\ *Department of Pediatrics and ${ }^{\ddagger}$ Department of Genetics and Center for Human Genetics, Case Western Reserve University, 8th Floor \\ BRB, 10900 Euclid Avenue, Cleveland, Ohio 44106-4948
}

\begin{abstract}
It has been reported that exhaled nitric oxide levels are reduced in cystic fibrosis (CF) patients. We have examined the inducible isoform of nitric oxide synthase (iNOS) in the airways by immunostaining and found that iNOS is constitutively expressed in the airway epithelia of non-CF mouse and human tissues but essentially absent in the epithelium of CF airways. We explored potential consequences of lost iNOS expression and found that iNOS inhibition significantly increases mouse nasal trans-epithelial potential difference, and hindered the ability of excised mouse lungs to prevent growth of Pseudomonas aeruginosa. The absence of continuous nitric oxide production in epithelial cells of $\mathrm{CF}$ airways may play a role in two CF-associated characteristics: hyperabsorption of sodium and susceptibility to bacterial infections. (J. Clin. Invest. 1998. 102:1200-1207.) Key words: guanylate cyclase - cGMP • ion transport • bactericidal
\end{abstract}

\section{Introduction}

Although much has been learned about the function and regulation of the cystic fibrosis transmembrane conductance regulator $(\text { CFTR })^{1}$ since its identification in $1989(1,2)$, it is still unclear how a defect in trans-apical chloride transport leads to the variety of airway symptoms associated with cystic fibrosis (CF). The causes of two common CF-associated airway abnormalities, hyperabsorption of sodium and chronic bacterial infection, remain mysteries. A loss of CFTR function may initiate a change in epithelial signaling cascades that adversely affects the function of vital cellular processes.

A direct or close physical interaction between CFTR and the epithelial sodium channel $(\mathrm{ENaC})$ has been proposed to explain CF-related sodium hyperabsorption $(3,4)$. Although

Address correspondence to Mitchell L. Drumm, Department of Pediatrics, Case Western Reserve University, 8th Floor BRB, 10900 Euclid Avenue, Cleveland, Ohio 44106-4948. Phone: 216-368-6893; FAX: 216-368-4223; E-mail: mxd34@po.cwru.edu

Received for publication 25 November 1997 and accepted in revised form 23 July 1998.

1. Abbreviations used in this paper: CFTR, cystic fibrosis transmembrane conductance regulator; $\mathrm{ENaC}$, epithelial sodium channel; GC-S, soluble guanylate cyclase; iNOS, inducible nitric oxide synthase; LPS, lipopolysaccharide; NO, nitric oxide.

J. Clin. Invest.

(C) The American Society for Clinical Investigation, Inc. 0021-9738/98/09/1200/08 \$2.00

Volume 102, Number 6, September 1998, 1200-1207

http://www.jci.org there is evidence for a physical interaction, these data do not explain all the phenomena associated with ENaC. For example, amiloride-sensitive sodium transport is stimulated by cAMP in renal distal tubules, even though these cells express both $\mathrm{CFTR}$ and $\mathrm{ENaC}(5,6)$. An alternative possibility is that the loss of some cellular signal in CF airway epithelia that normally serves to down-regulate sodium absorption may play a role in initiating the increased rate of sodium absorption. The process may be then further increased by altered protein kinase A regulation. A candidate for this lost signaling mechanism is nitric oxide (NO). NO is a known cell signaling agent that acts through the activation of soluble guanylate cyclases (GC-S), thus stimulating the production of cGMP (7). The ability of cGMP to effectively downregulate amiloride-sensitive sodium absorption has been demonstrated in several systems $(8,9)$. A loss of NO production would result in a loss of GC-S-mediated production of cGMP and presumably cause an increase in the rate of amiloride-sensitive sodium absorption. This model is consistent with several recent observations that exhaled NO levels are reduced in patients with CF (10-13). Although studies report little to no difference in orally exhaled NO levels between controls and CF patients, nasal NO levels are significantly reduced. Studying orally exhaled air, Grasemann et al. found a significant reduction in $\mathrm{NO}$ levels in $\mathrm{CF}$ patients compared with nonsmoking controls, especially when ambient room NO was taken into account (10). This study also found a positive correlation between NO levels and forced vital capacity. Their data suggest that lower levels of exhaled NO are an indication of more severe lung disease. Although not every study found a decrease in $\mathrm{NO}$ from orally exhaled air in CF patients compared with nondisease controls, there was clearly a lack of increased NO levels that would be expected in an inflammatory disease. Patients studied with asthma, for example, clearly have increased NO levels in orally exhaled air, serving as an indirect marker of inflammation (11). It is not clear why a chronically inflamed airway as is seen in $\mathrm{CF}$ does not exhibit this increase in NO production. This lack of NO production in CF airways occurs during chronic Pseudomonas aeruginosa infection, despite the fact that bacterial lipopolysaccharide (LPS) has been shown to stimulate NO production from airway macrophages and epithelial cells (14, 15). The inability of bacterial endotoxin to induce NO production in CF airway cells and the reported bactericidal activity of $\mathrm{NO}$ would suggest that an alteration in the NO pathway could result in the loss of a first-line epithelial defense mechanism.

Various reports have demonstrated that the inducible nitric oxide synthase isoform (iNOS) is constitutively expressed in tracheal and nasal epithelial cells in both rats and humans as well as human bronchial cells. This basal expression of iNOS by epithelial cells is apparently not due to iNOS induction by environmental factors since airway macrophages do not chronically express iNOS (16-18). Most cells can express iNOS when challenged with LPS or a combination of LPS and cytokines, such as interleukin-1 and tumor necrosis factor. How- 
ever, murine ileal mucosal cells and rat kidney epithelial cells have also been reported to continuously express iNOS in the absence of any cytokines or endotoxins $(19,20)$. These previous reports demonstrate that iNOS can play a role as a constitutively expressed source of NO production.

Tonic expression implies that iNOS activity has some regulatory role in airway epithelial cells. These roles can range from bactericidal activity to the regulation of gene expression, cell differentiation, epithelial microcirculation, and ciliary beat frequency. In this paper, we explore the differences in iNOS expression in $\mathrm{CF}$ and non-CF airway epithelial cells using a murine model and explore the possible role tonic NO production could have in explaining the $\mathrm{CF}$-associated symptoms of hyperabsorption of sodium and chronic bacterial infection.

\section{Methods}

Determination of NOS activity and nitrate/nitrite levels. NOS activity was determined by homogenizing whole murine trachea in $50 \mathrm{mM}$ Tris, pH 7.5, $1 \mathrm{mM}$ EDTA, $5 \mathrm{mM} \mathrm{KCl,} 2 \mathrm{mM} \mathrm{MgCl}_{2}$, and $0.1 \%$ polyethylene glycol $(8,000 \mathrm{~mol} w \mathrm{w})$ (buffer A). Homogenate was spun at $4^{\circ} \mathrm{C}$ at $14,000 \mathrm{rpm}$ in a microfuge for $15 \mathrm{~min}$. Supernatant was retained and protein concentration determined by protein assay according to the manufacturer's instructions (Dc; Bio-Rad, Melville, NY). Reactions contained 10-25 $\mu \mathrm{g}$ of protein, $10 \mu \mathrm{M}$ FAD, $200 \mu \mathrm{M}$ $\mathrm{NADPH}, 100 \mu \mathrm{M}$ tetrahydrobiopterin, $100 \mu \mathrm{M}$ L-arginine, and $1 \mathrm{mM}$ DTT in a $50-\mu l$ reaction volume in buffer A. Reactions were incubated for $90 \mathrm{~min}$ at $37^{\circ} \mathrm{C}$. After incubation, the whole mixture was assayed for nitrate/nitrite levels according to the manufacturer's instructions in the CalBiochem (La Jolla, CA) NO colorimetric assay kit. Values were compared with those obtained with a standard curve of varying nitrate concentrations and reported as $\mu \mathrm{M}$ of nitrate $/ \mathrm{h} / \mathrm{mg}$ of protein.

Ex vivo nitrate/nitrite levels were determined by preparing the tissue by perfusing the vasculature of the lung with Kreb's buffered Ringer's (KBR) containing ( $115 \mathrm{mM} \mathrm{NaCl}, 25 \mathrm{mM} \mathrm{NaHCO}_{3}, 5 \mathrm{mM}$ $\mathrm{KCl}, 2.5 \mathrm{mM} \mathrm{Na}_{2} \mathrm{HPO}_{4}, 1.8 \mathrm{mM} \mathrm{CaCl}_{2}, 1.0 \mathrm{mM} \mathrm{MgSO}_{4}$ ) through the heart until the lung turned white. PE-50 tubing was placed into the trachea and tied with suture. The lung and trachea were excised and lavaged five times with $1 \mathrm{ml}$ of KBR. After lavaging, $0.3 \mathrm{ml}$ of either KBR or KBR containing $10 \mu \mathrm{g} / \mathrm{ml}$ LPS from $P$. aeruginosa was infused into the lung, the PE tubing was capped, and the lung was placed in KBR bubbled with $95 \% \mathrm{O}_{2} / 5 \% \mathrm{CO}_{2}$ at $37^{\circ} \mathrm{C}$ for $1 \mathrm{~h}$. After incubation, the lung was relavaged with $0.5 \mathrm{ml}$ of $\mathrm{KBR}$ and the recovered lavage fluid assayed as described above for nitrate/nitrite levels.

iNOS-specific immunostaining. Lung sections of $\operatorname{cftr}(-/-)$ and $\operatorname{cftr}(+/+,-)$ mice were the kind gift of Thomas Ferkol, M.D., Case Western Reserve University, Cleveland, OH. Nasal epithelium was excised from $\mathrm{cftr}(-/-)$, cftr $(+/+)$, and NOS2 $(-/-)$ mice, paraffin blocked, and sectioned. Sections were deparaffinized, solubilized in ice-cold methanol for $5 \mathrm{~min}$, and placed in $2 \%$ goat immunoglobulin in PBS for $2 \mathrm{~h}$. Antibody against mouse and human iNOS was obtained from CalBiochem and incubated with the samples at $4^{\circ} \mathrm{C}$ overnight at a dilution of 1:300 in PBS. Samples were washed four times in PBS for $10 \mathrm{~min}$ per wash. Goat anti-rabbit IgG conjugated to alkaline phosphatase was diluted 1:200 in PBS and incubated with samples for $2 \mathrm{~h}$ at $37^{\circ} \mathrm{C}$. Samples were washed as before and stained for $20 \mathrm{~min}$ in Vector Red from Novacastra Laboratories Ltd. (Newcastle, UK) according to manufacturer's instructions, and slides were counter-stained with hematoxylin. Quantitation of staining was performed using ImagePro imaging software (Media Cybernetics, Silver Springs, MD).

Nasal trans-epithelial potential difference (TEPD) measurements. TEPD measurements were made as described previousl22y $(21,22)$. Mice treated with the iNOS inhibitor S-methylisothiourea (SMT) had $25 \mu \mathrm{l}$ of SMT $(100 \mathrm{mM})$ placed dropwise on their nostrils and were allowed to inhale each drop. Each mouse received three treatments a day ranging from $5-10 \mathrm{~h}$ between treatments for $2 \mathrm{~d}$. Mice were assayed 1-2 $\mathrm{h}$ after the final treatment. Aminoguanidine-treated mice received a single intraperitoneal injection of aminoguanidine (150 $\mathrm{mg} / \mathrm{kg}$ of body weight) and were assayed $1-1.5 \mathrm{~h}$ after injection.

Determination of bactericidal activity. Colony-forming units (CFUs) of the ampicillin-resistant laboratory strain of $P$. aeruginosa PAO1 or the clinical isolate strain of $P$. aeruginosa PA M57-15 added to each experiment was determined by growing the bacteria overnight in Luria broth (LB) and diluting until the desired density was obtained. Various aliquots were plated on LB-agar plates in triplicate and incubated overnight at $37^{\circ} \mathrm{C}$ and counted. For in vitro bacterial killing with sodium nitroprusside (SNP), $5 \mu$ of $1 \times 10^{5} \mathrm{CFU} / \mathrm{ml}$ was added to a $20-\mu l$ reaction volume with various concentrations of SNP in HBR (10 mM Hepes, pH 7.4, $138 \mathrm{mM} \mathrm{NaCl}, 5 \mathrm{mM} \mathrm{KCl}, 2.5 \mathrm{mM}$ $\mathrm{Na}_{2} \mathrm{HPO}_{4}, 1.8 \mathrm{mM} \mathrm{CaCl}_{2}, 1.0 \mathrm{mM} \mathrm{MgSO}$ ). Reactions were diluted in $\mathrm{HBR}$, plated on LB-agar plates in duplicate, incubated at $37^{\circ} \mathrm{C}$ overnight, and counted. For assays of bactericidal activity in excised mouse lung, 1,500-2,000 CFU/ml bacteria were used. Lungs were prepared as described above, and $300 \mu \mathrm{l}$ of diluted bacteria was placed in the lung and incubated for $1 \mathrm{~h}$ at $37^{\circ} \mathrm{C}$. Lavage fluid was plated in triplicate, incubated overnight, and counted. Experiments using PAO1 $P$. aeruginosa were plated on LB-agar plates containing ampicillin $(100 \mu \mathrm{g} / \mathrm{ml})$.

Mice. Mice were genotyped from tail-clip DNA. $\Delta$ F508 mice were a generous gift from Kirk Thomas from the University of Utah School of Medicine (Salt Lake City, UT) and were genotyped by the procedures described previously (23). CFTR (-/-) (24) and NOS2 $(-/-)(25)$ mice were obtained from Jackson Laboratories (Bar Harbor, ME), and cftr $(-/-)$ were genotyped as described by Koller et al. (26). To increase survival of CF animals, mice were fed a liquid diet as described by Eckman et al. (27). Mice were cared for in accordance with Case Western Reserve University IACUC guidelines.

\section{Results}

Expression and activity of airway iNOS in wild-type and $C F$ mice. The ability of wt mice and mice homozygous for the $\Delta$ F508 CFTR ( $\operatorname{cftr}(\Delta \mathrm{F} 508 / \Delta \mathrm{F} 508))$ mutation to produce NO in response to LPS challenge was tested by measuring the levels of nitrate/nitrite in lavage fluid of excised lungs. Nitrate in the samples was further reduced to nitrite as described in Methods, and samples were compared with a standard curve of varying nitrate concentrations; therefore, results are given as micromolar nitrate. Lavage fluid from the excised lungs of mice expressing wt CFTR in the absence of LPS contained $5.7 \pm 1.6 \mu \mathrm{M}$ nitrate $(n=3)$, whereas lungs treated for $1 \mathrm{~h}$ at $37^{\circ} \mathrm{C}$ with LPS $(10 \mu \mathrm{g} / \mathrm{ml})$ were found to have levels of $27.1 \pm 7.6 \mu \mathrm{M}$ nitrate $(n=4)$ (Fig. $1 A)$. The LPS-mediated increase in NO production appears to be iNOS-dependent. Coincubation with the iNOS-specific inhibitor SMT $(100 \mu \mathrm{M})$ prevented LPS-mediated increases in NO production, reducing recovered nitrate values to $4.3 \pm 2.6 \mu \mathrm{M}$ nitrate $(n=3)$. Lungs excised from cftr $(\Delta \mathrm{F} 508 / \Delta \mathrm{F} 508)$ mice failed to respond similarly to LPS. Lavage fluid from untreated cftr $(\Delta \mathrm{F} 508 /$ $\Delta \mathrm{F} 508)$ mouse lungs contained $2.4 \pm 1.6 \mu \mathrm{M}$ nitrate $(n=3)$ compared with $2.0 \pm 1.0 \mu \mathrm{M}$ nitrate $(n=3)$ in LPS-treated lungs. Similar results are observed when the NOS substrate L-arginine is incubated with excised lung. The addition of L-arginine $(100 \mu \mathrm{M})$ in excised lungs from $\mathrm{cftr}(+/+, \Delta \mathrm{F} 508)$ increases nitrate values to $42.2 \pm 10.0 \mu \mathrm{M}(n=5)$, whereas lungs from $\operatorname{cftr}(\Delta \mathrm{F} 508, \Delta \mathrm{F} 508)$ only generate $6.4 \pm 6.2 \mu \mathrm{M}$ nitrate $(n=2)$ in response to L-arginine.

To determine if there is a quantitative difference in NOS activity in mouse airways, total NOS activity was measured 
A

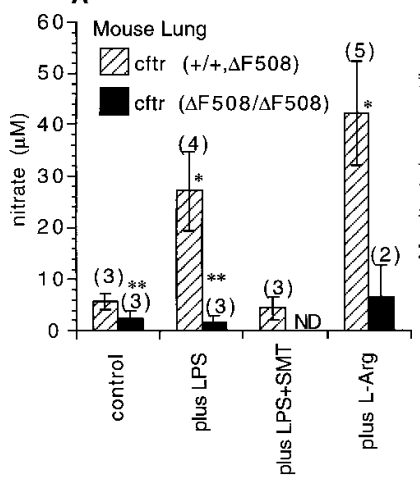

Figure 1. Airway NOS activity. (A) Nitrate/nitrite levels recovered from the excised lungs of wt $(\mathrm{cftr}(+/+, \Delta \mathrm{F} 508))$ and $\Delta \mathrm{F} 508$ (cftr $(\Delta \mathrm{F} 508 / \Delta \mathrm{F} 508))$ mice in the presence of either LPS $(10 \mu \mathrm{g} / \mathrm{ml})$, L-arginine $(100 \mu \mathrm{M})$, or LPS + SMT $(100 \mu \mathrm{M})$. CFTR $(+/+, \Delta$ F508) refers to both wild type homozygous and $\Delta \mathrm{F} 508$ heterozygous animals. *Values significantly higher $(P<0.01)$ than wt control; **values significantly lower $(P<0.05)$ than wt control. $P$ values determined by Duncan's multiple range test. Number of experiments for each condition is given in parentheses. (B) NOS-specific activities of whole trachea homogenates from $\operatorname{cftr}(-/-)$ mice and nonsibling heterozygous controls, as well as from $\mathrm{cftr}(\Delta \mathrm{F} 508 / \Delta \mathrm{F} 508)$ mice and agematched heterozygous siblings. *Values significantly greater $(P<$ 0.05 ) than those obtained from homozygous mice as determined by $t$ test. Number of experiments for each group is given in parentheses. Error bars represent SEM.

from whole trachea taken from both $\mathrm{CF}$ and non-CF mice. Mice carrying mutations that prevent CFTR expression [cftr $(-/-)$ mice] were found to have a specific activity of $67.1 \pm 42.1$ $\mu \mathrm{M}$ nitrate $/ \mathrm{h} / \mathrm{mg}$ of protein $(n=4)$ compared with $255 \pm 57.5$ $\mu \mathrm{M}$ nitrate $/ \mathrm{h} / \mathrm{mg}$ of protein $(n=3)$ in nonsibling non-CF mice (Fig. $1 B$ ). A similar difference was found comparing NOS activity in trachea from $\mathrm{cftr}(\Delta \mathrm{F} 508 / \Delta \mathrm{F} 508)$ mice and agematched siblings. Total NOS activity from $\mathrm{cftr}(\Delta \mathrm{F} 508 / \Delta \mathrm{F} 508)$ mice was found to be $13.3 \pm 6.7 \mu \mathrm{M}$ nitrate $/ \mathrm{h} / \mathrm{mg}$ of protein $(n=3)$ compared with $311.3 \pm 86.2 \mu \mathrm{M}$ nitrate $/ \mathrm{h} / \mathrm{mg}$ of protein $(n=3)$ from siblings, suggesting that total NO production is reduced in the airways of mice carrying $\mathrm{CF}$ mutations.

iNOS is reported to be continuously expressed in the airway epithelium of humans, suggesting that this isoform is largely responsible for the production of NO in airways (18). Immunohistochemistry using a polyclonal antibody against iNOS was used to test directly for iNOS expression in lung sections taken from cftr $(-/-)$ and $\mathrm{cftr}(+/+,-)$ mice and in sections of human trachea from $\mathrm{CF}$ and non-CF subjects. As shown in Fig. 2, the airway epithelium from a normal mouse shows high expression of iNOS compared with the epithelium of a cftr (-/-) mouse, consistent with the above data showing reduced $\mathrm{NO}$ production in $\mathrm{CF}$ mice. To address the question of specificity of the iNOS antibody, nasal epithelia were excised and sectioned from cftr $(-/-)$ and $\operatorname{cftr}(+/+)$ mice, as well as mice that lack the expression of the inducible form of NOS [NOS2 (-/-)] as a control (Fig. 3). Immunostaining of nasal epithelial sections from the NOS2 $(-/-)$ mouse reveals no detectable expression of iNOS protein and no detectable cross-reactivity with either endothelial NOS or neuronal NOS, both of which are reportedly normally expressed in the NOS2 $(-/-)$ mice (27). Nasal epithelium was chosen for these stud-
A
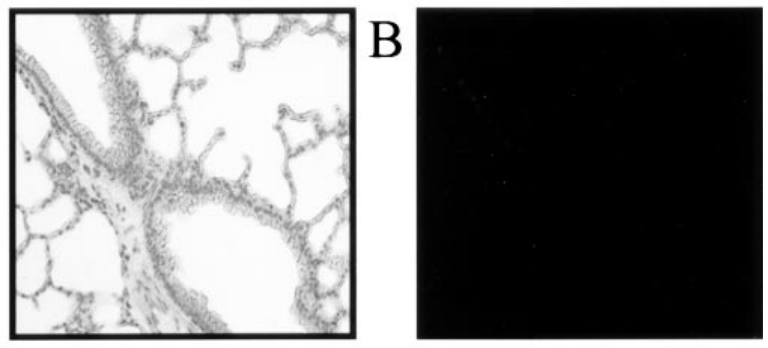

$\mathrm{C}$
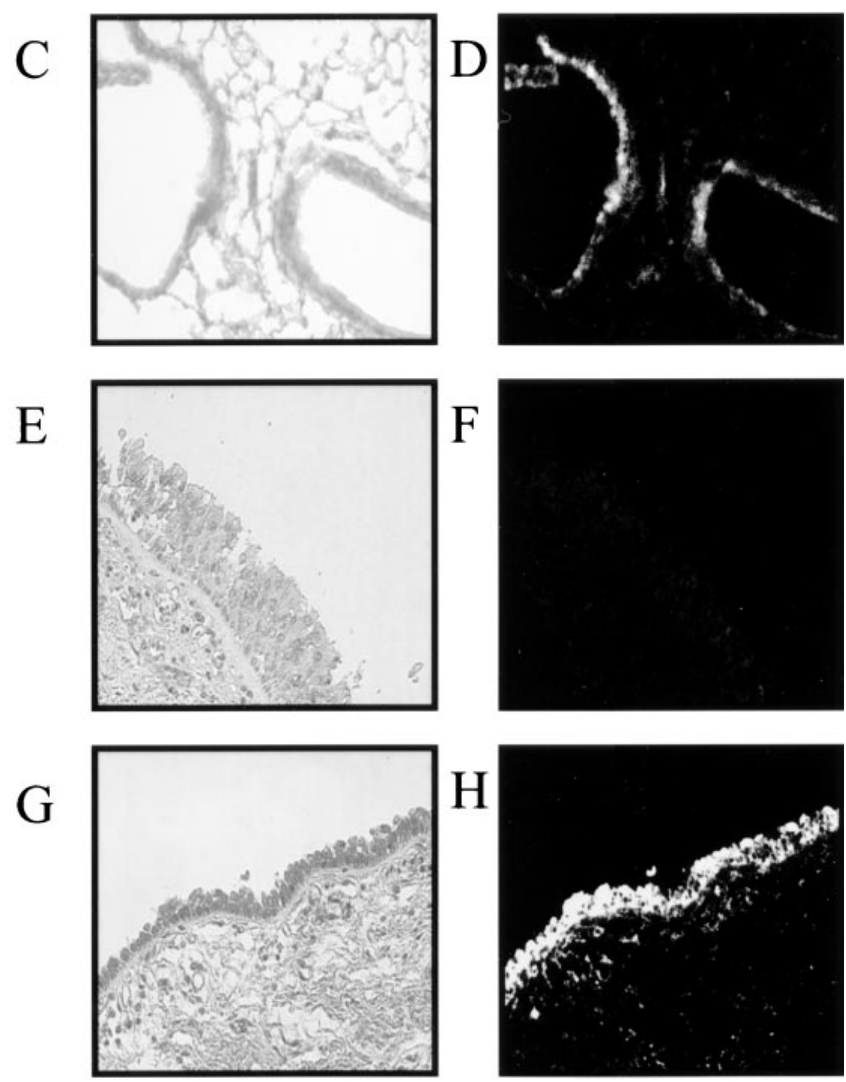

Figure 2. iNOS-specific immunostaining in sections from $\mathrm{CF}$ and non-CF mouse lung and $\mathrm{CF}$ and non-CF human trachea. $A, C, E$, and $G$ show sections of $\operatorname{cftr}(-/-)$ mouse lung, $\operatorname{cftr}(+/-)$ mouse lung, CF human trachea, and a non-CF human trachea, respectively. $B, D, F$, and $H$ show fluorescence through a rhodamine filter of anti-iNOS IgG binding in corresponding fields.

ies to compare iNOS expression in upper respiratory epithelial cells with expression in the lower airways. Since the lack of iNOS expression is maintained in CF nasal epithelial cells, the effects of a lack of iNOS expression on various ion transport parameters can be examined. Also consistent with previous reports, there is high expression of iNOS in the epithelium of non-CF human trachea. The human $\mathrm{CF}$ tracheal tissue, however, shows very little iNOS staining in the epithelium, supporting previous findings that exhaled nasal NO levels are reduced in patients with CF (13). These mice have not been infected or exposed to exogenous cytokines or endotoxins, suggesting that iNOS is continuously expressed in non-CF murine epithelium as is seen in human airway epithelium.

Effect of decreased NO production on amiloride-sensitive sodium absorption. NO is an effective activator of GC-S, and cGMP is a known regulator of amiloride-sensitive sodium ab- 

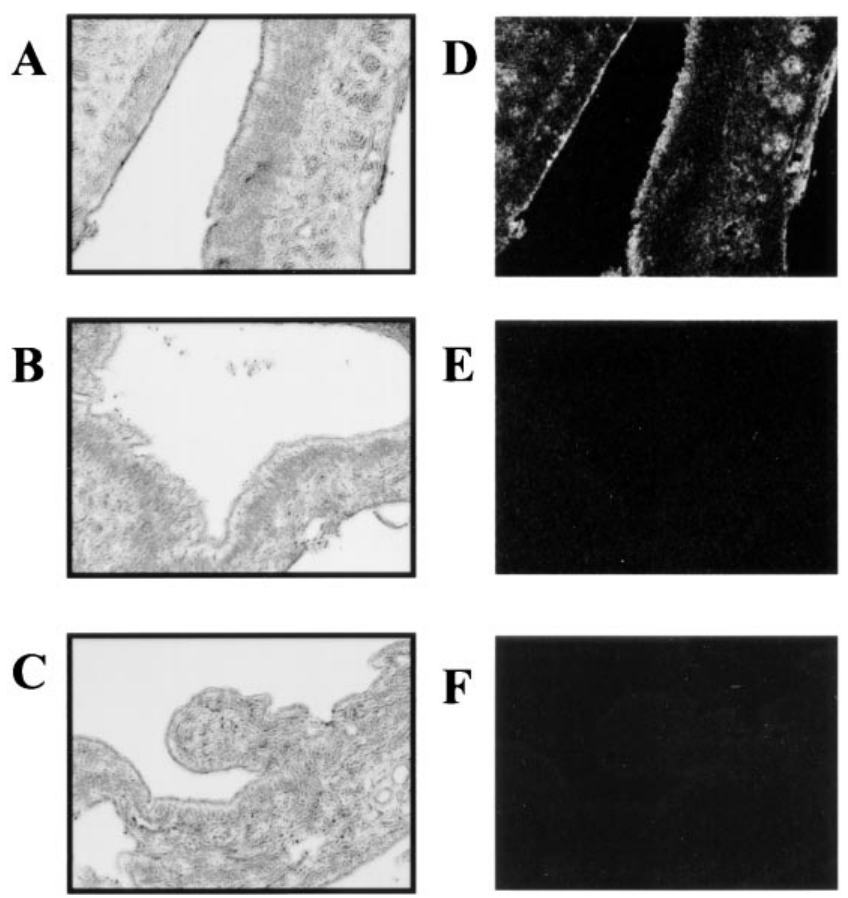

Figure 3. iNOS-specific immunostaining in sections from cftr $(+/+)$, $\operatorname{cftr}(-/-)$, and NOS2 $(-/-)$ mouse nasal epithelium. $A, B$, and $C$ show bright field views of sections from $\mathrm{cftr}(+/+), \operatorname{cftr}(-/-)$, and NOS2 (-/-) mouse nasal epithelium, respectively. $D, E$, and $F$ show fluorescence through a rhodamine filter of anti-iNOS IgG binding in corresponding fields.

sorption (9). To assess a possible role of decreased iNOS expression in the CF-related characteristic of sodium hyperabsorption, the effects of the NO donor SNP on tracheal cGMP production and on nasal TEPD were tested.

Using excised whole trachea, $\operatorname{cftr}(\Delta \mathrm{F} 508 / \Delta \mathrm{F} 508)$ mice responded approximately sevenfold more to SNP than non-CF mice in their ability to produce cGMP in the presence of NO (Fig. $4 A$ ). Levels of cGMP increased from $443.7 \pm 173.2 \mathrm{fmol}$ of cGMP/mg of protein $(n=5)$ in untreated cftr $(+/+, \Delta$ F508) mice to $665.0 \pm 143.8 \mathrm{fmol}$ of $\mathrm{cGMP} / \mathrm{mg}$ of protein $(n=5)$ in mice treated with SNP $(100 \mu \mathrm{M})$. However, $\operatorname{cftr}(\Delta \mathrm{F} 508 /$ $\Delta$ F508) mice showed increases from 427.2 \pm 125.7 fmol of $\mathrm{cGMP} / \mathrm{mg}$ of protein $(n=3)$ in untreated trachea to $4605.6 \pm$ $1951.3 \mathrm{fmol}$ of cGMP/mg of protein $(n=3)$ in SNP-treated trachea. These data show that CF airways appear to be hypersensitive to exogenous NO addition, possibly due to an upregulation of NO-sensitive guanylate cyclase in the absence of tonic NO production by the epithelium. Despite a clearly altered reaction to exongenously added NO, basal levels of cGMP in CF and non-CF mouse trachea appear to be very similar. This finding may be due to the fact that whole tracheas were used as opposed to isolated epithelial cells, and cGMP levels from other cell types are being detected in the basal measurement. Similarly, there may be high turnover of cGMP produced through NO-dependent guanylate cyclases since our hypothesis would suggest that this pool of cGMP would be important in regulating a sensitive ion transport process, thus not contributing significantly to total cGMP content.

If increased NO does reduce airway epithelial sodium absorption, the above findings predict that exogenously added SNP will reduce nasal TEPD in mice carrying CFTR muta-
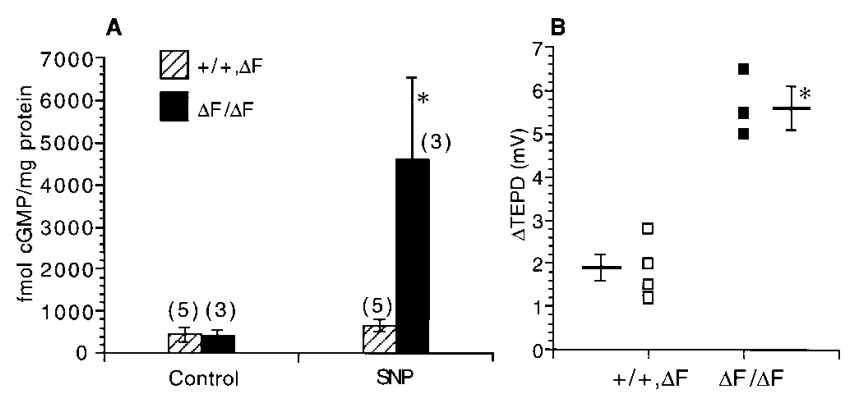

Figure 4. Differential effects of NO in cftr $(+/+, \Delta \mathrm{F} 508)$ and cftr $(\Delta$ F508/ $\Delta$ F508) airways. (A) Production of cGMP stimulated by the addition of the NO donor SNP in excised whole tracheas. Number of experiments for each group is given in parentheses. Error bars represent SEM. $* P=0.002$ as determined by Duncan's multiple range test compared with cftr $(+/+, \Delta \mathrm{F} 508)$ control group. $(B)$ Change in nasal TEPD stimulated by the addition of SNP in cftr $(+/+, \Delta$ F508) and cftr $(\Delta \mathrm{F} 508 / \Delta \mathrm{F} 508)$ mice. Average baseline TEPD values were $9.0 \pm 0.9$ $\mathrm{mV}$ and $29.8 \pm 1.6 \mathrm{mV}$ for $\mathrm{cftr}(+/+, \Delta \mathrm{F} 508)$ and $\operatorname{cftr}(\Delta \mathrm{F} 508 / \Delta \mathrm{F} 508)$ mice, respectively. ${ }^{*} P=0.002$ as determined by $t$ test.

tions. Comparing age-matched mice from the same colony, cftr $(+/+, \Delta \mathrm{F} 508)$ mice showed a $1.9 \pm 0.3 \mathrm{mV}(n=4)$ depolarization of nasal TEPD in the presence of SNP $(100 \mu \mathrm{M})$, while SNP induced a $5.5 \pm 0.5 \mathrm{mV}(n=3)$ depolarization of nasal TEPD in $\operatorname{cftr}(\Delta \mathrm{F} 508 / \Delta \mathrm{F} 508)$ mice (Fig. $4 B)$.

The differences in TEPD and sodium absorption characteristic of CF airways should be mimicked by the inhibition of NOS activity if NO plays an important role in the tonic regulation of ion transport. Using the iNOS-selective inhibitor SMT, which we have previously shown to inhibit LPS-induced NO production in excised mouse lung, we examined its effects on amiloride- and SNP-sensitive sodium absorption in mouse nasal epithelia. Nasal TEPD values before treatment with SMT for $\operatorname{cftr}(+/+,-)$ mice averaged $-8.3 \pm 0.6 \mathrm{mV}(n=7)$. Mice were treated by placing $25 \mu$ l of a high concentration of SMT $(100 \mathrm{mM})$ over the nostrils and letting the mice inhale the solution through the nasal cavity. After three treatments over a 2-d period with SMT, baseline TEPD increased to $-14.9 \pm 0.8 \mathrm{mV}$ ( $n=7, P=0.0005$ ) (Fig. 5). $3 \mathrm{~d}$ after the last SMT exposure, baseline TEPD values of tested mice returned to $-8.2 \pm 1.6$ $\mathrm{mV}(n=3)$ (data not shown). This experiment was also performed in a blinded fashion, where either Ringer's or SMT (100 mM) was administered to the mice and nasal TEPD measurements were performed blinded. Mice treated with Ringer's had baseline nasal TEPD values of $-6.1 \pm 0.8 \mathrm{mV}$ and $-6.6 \pm 1.1 \mathrm{mV}$ before and after treatment, respectively. Mice treated with SMT, however, showed an increase of baseline nasal TEPD values from $-8.0 \pm 1.0 \mathrm{mV}$ to $-16.0 \pm 1.7 \mathrm{mV}$ (data not shown; $n=4, P=0.02$ ). Depolarization of TEPD induced by amiloride $(100 \mu \mathrm{M})$ increased in magnitude from $3.0 \pm 0.4 \mathrm{mV}$ before treatment to $5.1 \pm 0.4 \mathrm{mV}(n=4)$ after SMT treatment, although the percentage change was not significantly altered. Due to a slow, continued depolarization of TEPD in the presence of amiloride, stable plateau values were not consistently reached. Therefore, the above values were taken 2 min after the addition of amiloride and likely underestimate the contributions of amiloride-sensitive sodium absorption to TEPD. To confirm that these changes were due to iNOS inhibition, a second iNOS-selective inhibitor was tested. Aminoguanidine $(150 \mathrm{mg} / \mathrm{kg}$ of body weight) was injected in- 
A

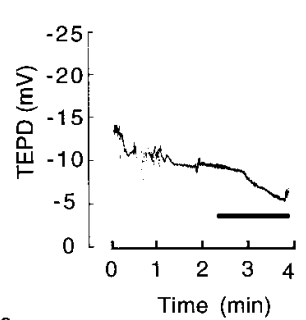

C
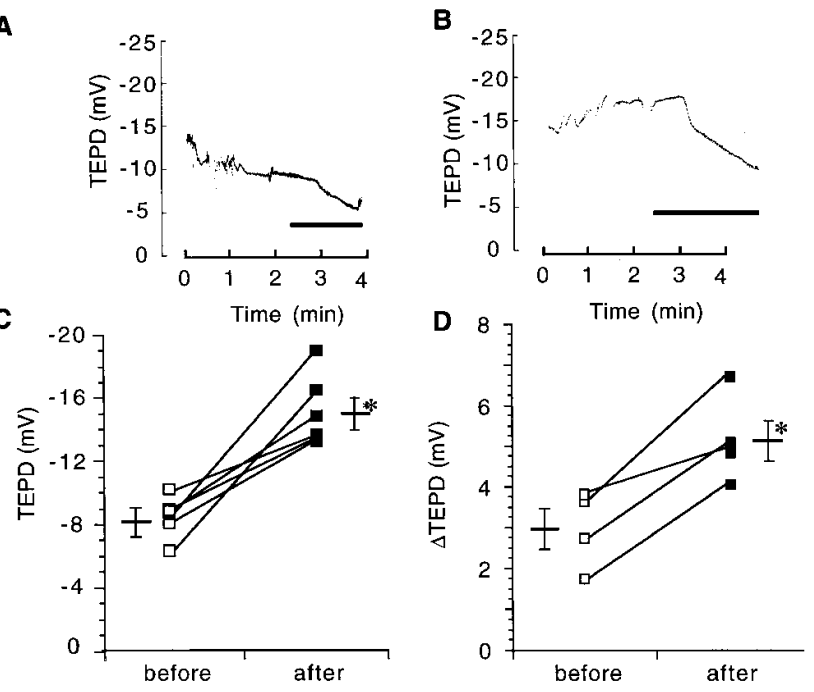

E

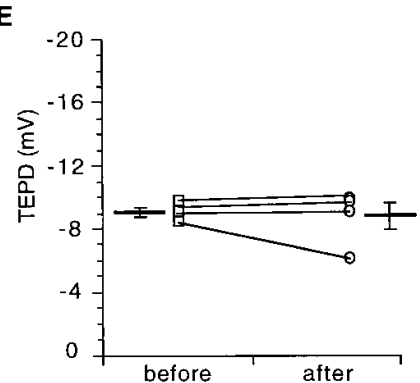

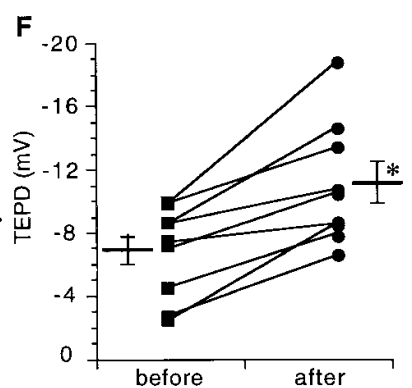

Figure 5. Effect of iNOS inhibition on baseline TEPD in cftr $(+/$ $+,-)$ mice. $A$ and $B$ show raw traces of a wt mouse $(A)$ before and $(B)$ after treatment with SMT. Solid bar shows the presence of amiloride. $C$ shows cftr $(+/+,-)$ mice before and after treatment with SMT, and $D$ shows the magnitude of the depolarization of lumen negative TEPD due to amiloride. Changes in amiloride were measured at $4 \mathrm{~min}$, and plateau values were not always reached. $E$ shows control mice injected with vehicle (PBS), while $F$ shows baseline TEPD values of mice before and after receiving intraperitoneally injected aminoguanidine. Error bars represent SEM. $* P<0.05$ as determined by $t$ test.

traperitoneally approximately $1-1.5 \mathrm{~h}$ prior to nasal TEPD assay (24). Nasal TEPD values increased from $-7.1 \pm 1.4 \mathrm{mV}$ prior to treatment to $-11.7 \pm 2.4 \mathrm{mV}(n=9)$ within $1.5 \mathrm{~h}$ after injection (Fig. 5, $E-F$ ). Mice injected with PBS, which was used as the vehicle, showed no change in TEPD. These data suggest that iNOS regulates baseline TEPD by reducing trans-epithelial sodium absorption.

The product of iNOS, NO, is known to stimulate the production of cGMP through the activation of NO-sensitive GC-S. To determine if NO is capable of regulating sodium absorption through this pathway, we used the GC-S-specific inhibitor ODQ and looked at its effects on trans-epithelial sodium absorption. Perfusing the nasal epithelium of $\operatorname{cftr}(+/+,-)$ mice with ODQ resulted in a hyperpolarization of TEPD from $-6.9 \pm 0.6 \mathrm{mV}$ to $-11.8 \pm 1.8 \mathrm{mV}(n=5)$ within $3 \mathrm{~min}$ after the start of perfusion (Fig. 6). Pretreatment with either amiloride or the cGMP analog 8-Br-cGMP prevented ODQmediated hyperpolarization of TEPD, suggesting that NO influences amiloride-sensitive sodium absorption through cGMP production.

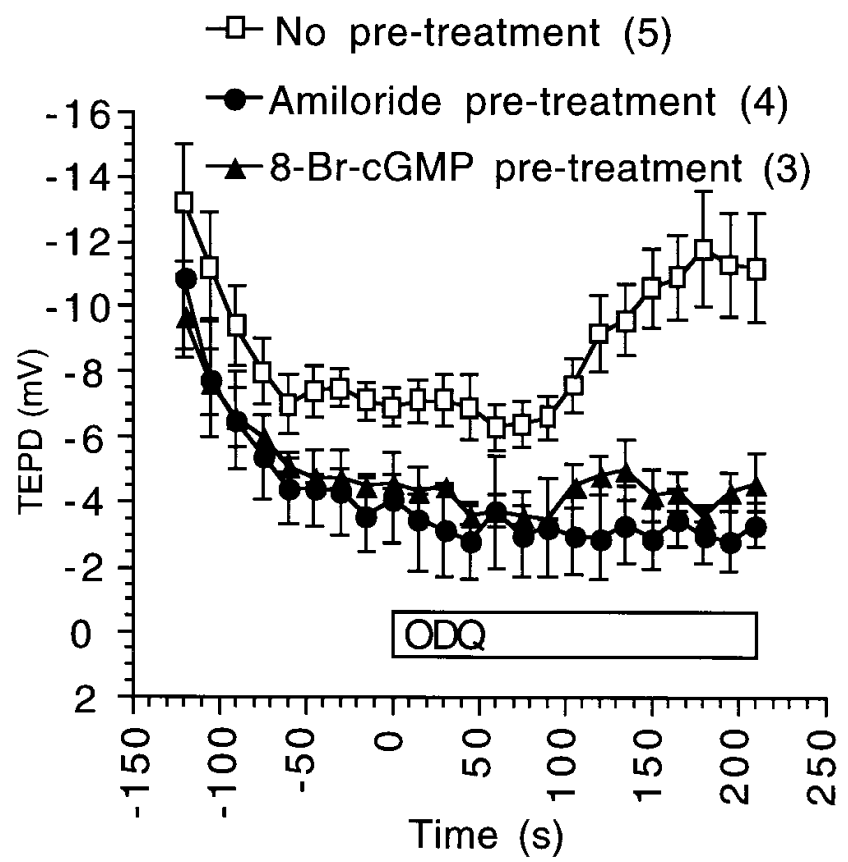

Figure 6. The effects of GC-S inhibition on mouse nasal TEPD in cftr $(+/+,-)$ mice. The effect of the GC-S inhibitor ODQ $(100 \mu \mathrm{M})$ on mouse nasal TEPD without pretreatment $(\square)$ or in the presence of either amiloride $(100 \mu \mathrm{M})(\mathbf{\bullet})$ or 8 -Br-cGMP $(100 \mu \mathrm{M})(\mathbf{\Delta})$. The presence of ODQ is shown by the open bar. Number of experiments for each group is given in parentheses. Error bars represent SEM.

$N O$ as an epithelial defense mechanism against bacterial infections. Previous reports demonstrate that NO is an effective bactericidal agent (28-31). We show that the NO donor, SNP, is capable of killing bacteria in a concentration-dependent manner. SNP concentrations ranging from $10^{-7}$ to $10^{-3} \mathrm{M}$ were used to look at bactericidal activity of $\mathrm{NO}$ with the $P$. aeruginosa strain PAO1 (Fig. 7). Significant decreases in bacterial recovery were achieved with $750 \mathrm{nM}$ SNP, with subsequently higher concentrations of SNP having more pronounced bactericidal activity when a limited number of bacteria $(\sim 500$ CFU) were used. When larger amounts of PAO1 were used ( $>10,000 \mathrm{CFU})$, millimolar amounts of SNP were needed to kill bacteria (data not shown). Bactericial activity was due to NO production rather than nonspecific toxicity of SNP, since the NO scavenger $N$-methyl-D-glucamine dithiocarbamate effectively prevented SNP-mediated killing of PAO1 (Fig. $7 \mathrm{~B}$ ).

$\mathrm{NO}$ has also been shown to be a significant mediator of murine resistance to airway infection by $P$. aeruginosa (31). Injection of the normally infection-resistant BALB/c mice with the NOS inhibitor aminoguanidine severely decreased their ability to control the growth of $P$. aeruginosa. Aminoguanidine had no effect, however, on the infection-susceptible DBA/2 mice, suggesting that reduced NO production in the $\mathrm{DBA} / 2$ mice is a factor in their increased susceptibility to $P$. aeruginosa infection. Since our earlier experiments had shown that excised lungs from $\operatorname{cftr}(\Delta \mathrm{F} 508 / \Delta \mathrm{F} 508)$ mice were deficient in their ability to produce NO in response to LPS compared with wt mice, the ability of excised lungs from these groups of mice to kill bacteria were compared. In all bactericidal experiments, a KBR solution containing $115 \mathrm{mM} \mathrm{NaCl}$ and $5 \mathrm{mM} \mathrm{KCl}$ was used to eliminate bacterial killing by salt-sensitive antibacterial 


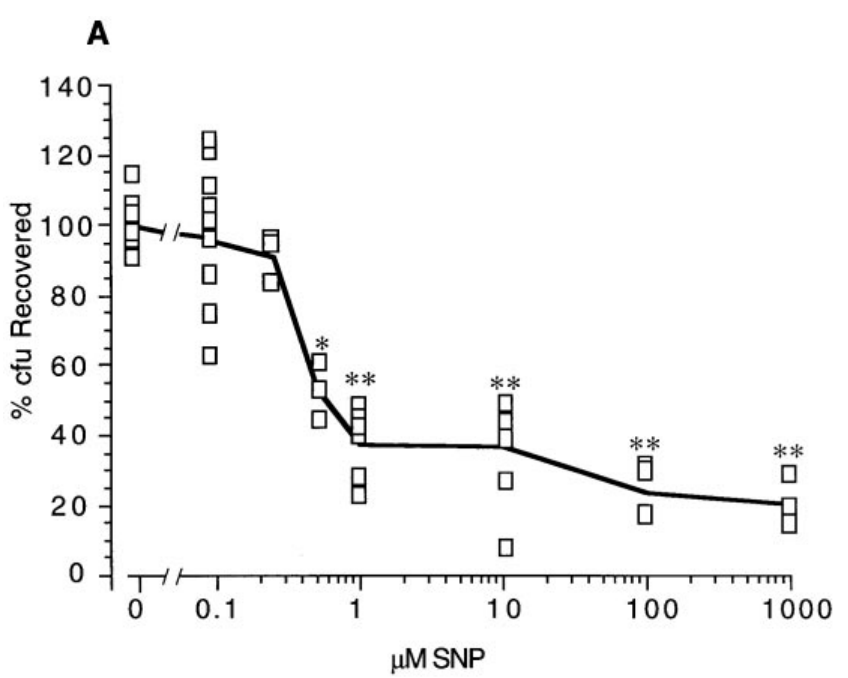

B

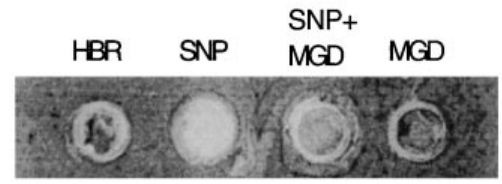

PA M57-15

Figure 7. Bactericidal activity of NO. (A) PAO1 bacteria ( $424 \pm 69$ cfu/reaction) were incubated with various concentrations of the NO donor SNP. The solid line connects the mean \%cfu recovered for each concentration. $* P=0.0001$ and $* * P<0.00005$ as determined by Duncan's multiple range test compared to CFU recovered in the absence of SNP. Each point represents an individual reaction. $(B)$ PAO1 ( $>10,000 \mathrm{CFU}$ ) was streaked on a plate and bacterial growth was tested in the presence of (1) Hepes-buffered Ringer's (HBR), (2) $50 \mathrm{mM}$ SNP, (3) $50 \mathrm{mM} \mathrm{SNP}+50 \mathrm{mM}$ MGD (a NO scavanger), and (4) $50 \mathrm{mM}$ MGD.

peptides $(32,33)$. Adding approximately $500 \mathrm{CFU}$ of either PAO1 or the clinical isolate PA M57-15 to each lung, only $68 \pm 20 \mathrm{CFU}(n=9)$ were recovered from the lungs of wt mice (Fig. 8). However, 994 $\pm 208 \mathrm{CFU}$ of PAO1 were recovered from $\operatorname{cftr}(\Delta \mathrm{F} 508 / \Delta \mathrm{F} 508)$ mice $(n=3)$. The iNOS inhibitor, SMT, is capable of eliminating the ability of wt mice to produce NO in response to LPS, mimicking the result found with the $\operatorname{cftr}(\Delta \mathrm{F} 508 / \Delta \mathrm{F} 508)$ mice and their inability to produce NO in response to LPS. The bactericidal activity apparently endogenous to wt mouse lung was tested in the presence of SMT to determine if iNOS has a potential role in antibacterial epithelial defense mechanisms. Using both PAO1 and the clinical isolate of $P$. aeruginosa, PA M57-15, bactericidal activity in excised lungs was tested in the presence of SMT. Again with $\sim 500 \mathrm{CFU}$ of either PAO1 or PA M57-15 added to each excised lung, an average of $400 \pm 69 \mathrm{CFU}(n=7)$ were recovered from SMT-treated lungs. Excised lungs challenged with a low level inoculum of bacteria were used to approximate initial bacterial challenge to an airway lumen and to avoid artifacts of cultured epithelial cells. The contributions of lumenal macrophages were minimized by removal through lavage. How NO affects more chronic, in vivo bacterial challenges in murine airways remains to be determined. These data suggest that en-

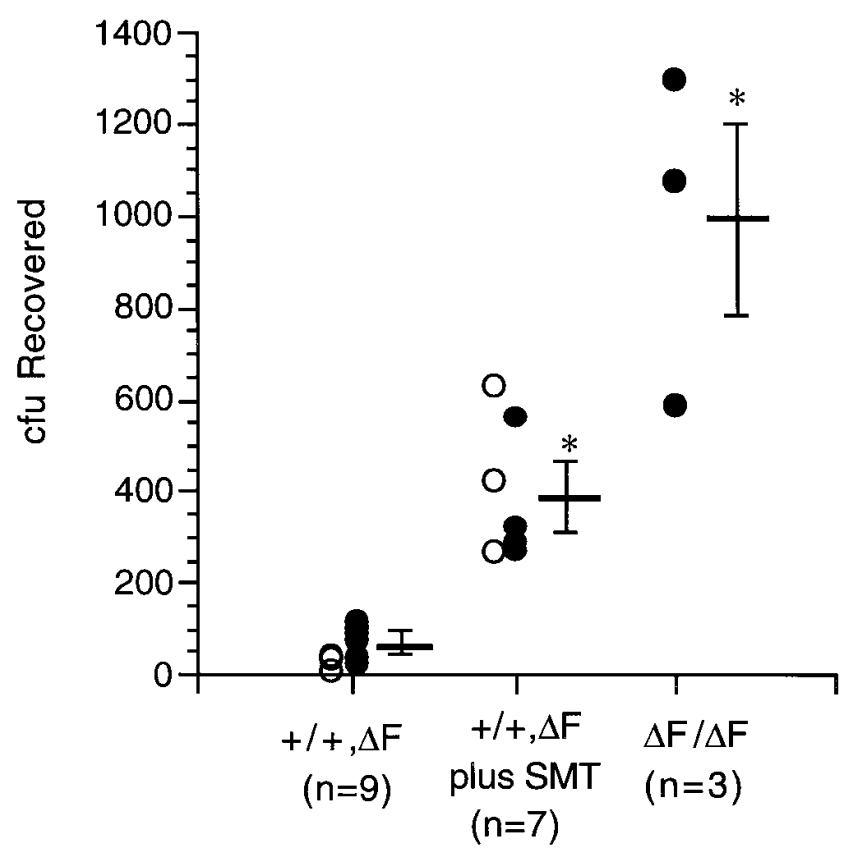

Figure 8. Comparison of $P$. aeruginosa killing in excised lungs of cftr $(+/+, \Delta \mathrm{F} 508)$ and $\operatorname{cftr}(\Delta \mathrm{F} 508 / \Delta \mathrm{F} 508)$ mice. PAO1 $(\bullet)$ and a clinical isolate PA M57-15 $(\bigcirc)$ were tested in $\mathrm{cftr}(+/+, \Delta \mathrm{F} 508)$ in the presence and absence of the iNOS inhibitor SMT. An average of $541 \pm 32$ CFU of $P$. aeruginos $a$ were used for each assay. Solid bars indicate average CFU recovered and error bars represent SEM. Each point shows an individual experiment. $* P<0.05$ as determined by $t$ test compared with CFU recovered from $\operatorname{cftr}(+/+, \Delta \mathrm{F} 508)$ in the absence of SMT.

dogenously produced NO may have a role in preventing the initiation of bacterial infections in the airways.

\section{Discussion}

Exhaled air from CF patients has been shown to contain decreased amounts of NO despite chronic bacterial infection and inflammation (10). This finding is inconsistent with other inflammatory airway diseases, such as asthma where exhaled NO levels are significantly increased $(11,31-37)$. Possible explanations for this discrepancy are that either poorly cleared mucous prevents the highly reactive NO from reaching air spaces to be expelled or that bacterial NO reductase activity eliminates NO produced in the airways. Based on evidence that iNOS is a constitutively expressed isoform in airway epithelial cells, we examined whether iNOS expression and function were reduced in $\mathrm{CF}$ airways using both $\mathrm{cftr}(-/-)$ and $\mathrm{cftr}$ $(\Delta \mathrm{F} 508 / \Delta \mathrm{F} 508)$ mice as model systems. We found that total NOS-specific activity was greatly reduced in the trachea of $\mathrm{CF}$ mice compared with wt controls and that excised mouse lungs from CF mice fail to produce NO in response to LPS challenge or to the NOS substrate L-arginine. These data establish that there is a functional difference in the ability of airways of $\mathrm{CF}$ mice to produce NO compared with wt controls. Also, immunostains specific for the iNOS isoform in both human tracheal and murine lung sections clearly show that iNOS is constitutively expressed in airway epithelial cells of non-CF airways and nearly absent in the epithelium of CF airways. These data 
are consistent with other reports that show iNOS expression in airway epithelial cells from various sources and offer a possible explanation for the lack of exhaled $\mathrm{NO}$ in $\mathrm{CF}$ patients. By analogy, these observations suggest that reduced expired NO from CF patients may not be a direct consequence of infection of inflammation, but rather a reduction in iNOS expression resulting from reduced CFTR function.

We have also explored possible consequences of chronic loss of iNOS expression in airway epithelial cells. An initial consequence is that trachea from $\mathrm{CF}$ mice appear to be hypersensitive to exogenously added NO when measured by induced cGMP production. Non-CF mice increased cGMP levels only 1.5 -fold in the presence of the NO donor SNP, while trachea from CF mice showed a 10.8 -fold increase. Our data indicate that this phenomenon may not be observable in cultured airway cells. We have seen that even non-CF airway cells placed in culture fail to produce iNOS and exhibit increased production of cGMP in response to SNP (data not shown). This observation is consistent with a previous report that demonstrates airway epithelial cells cultured ex vivo lose their iNOS expression (12). The lack of iNOS expression in cultured cells would help explain apparent differences in cGMP production in response to SNP previously shown in non-CF airway epithelial cells. Human airway cells placed in primary culture show equal response to both C-type natriuretic peptide and SNP in stimulated production of cGMP (38). Our own report shows that Calu-3 cells produce significant amounts of cGMP in response to SNP (39). We have found neither iNOS activity nor expression associated with our cultures of Calu-3 cells (data not shown). A possible explanation for this effect is that NO-sensitive elements such as GC-S are upregulated in the absence of constitutive NO production. The mechanisms behind these differences will need to be explored in greater detail.

Amiloride-sensitive sodium absorption is known to be regulated by cGMP in several systems. A lack of NO production would theoretically reduce GC-S-mediated cGMP production and result in the loss of a negative-regulatory effector of sodium absorption. This mechanism would offer a possible explanation for the poorly understood CF characteristic of hyperabsorption of sodium across airway epithelium. We have shown increased sodium absorption in response to iNOS inhibition using two different inhibitors, SMT and aminoguanidine. We have also shown that inhibition of the NO-sensitive GC-S with the inhibitor ODQ results in hyperpolarization of nasal epithelia, directly implicating NO-induced cGMP as a tonic regulator of sodium transport. The NO donor SNP also produced a greater magnitude of epithelial depolarization both in cftr $(\Delta \mathrm{F} 508 / \Delta \mathrm{F} 508)$ mice and SMT-treated wt mice compared with untreated wt mice. It is likely that other factors contribute to increased sodium transport in $\mathrm{CF}$ airways such as atypical PKA regulation of $\mathrm{ENaC}$ (3) or abnormal ion gradients due to a lack of CFTR function. Other sodium transport mechanisms are known to be regulated by NO. Both $\mathrm{Na}^{+} / \mathrm{K}^{+}$ATPase and $\mathrm{Na}^{+} / \mathrm{H}^{+}$exchanger have been shown to be inhibited by NO-dependent mechanisms in porcine cerebral cortex and rabbit proximal tubule, respectively, although the exact mechanisms of inhibition are not well understood $(40,41)$. NO has also been reported to stimulate $\mathrm{Na}^{+} / \mathrm{K}^{+}$-ATPase human corpus cavernosum smooth muscle, further complicating the understanding of this regulatory process (42). These reports, coupled with those that describe NO and cGMP regulation of amiloride-sensitive sodium absorption in vascular and intestinal tissues, demonstrate that NO is a potent paracrine or autocrine regulator of sodium transport through a variety of mechanisms. Although more study is needed, a loss of NO production resulting in the loss of subsequent signaling cascades represents a potential mechanism for initiating the process of sodium hyperabsorption in $\mathrm{CF}$ airways.

Another possible consequence of decreased iNOS expression and activity would be a loss of an initial defense mechanism against bacterial infection. Bactericidal activity has been associated with NO and its production is stimulated by bacterial endotoxins and cytokines. Losing the ability to express the iNOS isoform in particular would hinder the ability of the epithelium to defend itself against bacterial challenge. We have demonstrated that airways of $\operatorname{cftr}(\Delta \mathrm{F} 508 / \Delta \mathrm{F} 508)$ mice are diminished in their ability to clear strains of $P$. aeruginosa. NonCF mice, however, are capable of bactericidal activity even in a high-salt Ringer's, which should eliminate contributions of salt-sensitive defensin peptides (32). The antibacterial activity of non-CF airways was significantly reduced by the presence of the iNOS-specific inhibitor SMT, mimicking the inability of the $\operatorname{cftr}(\Delta \mathrm{F} 508 / \Delta \mathrm{F} 508)$ lungs to kill PAO1 bacteria. It is likely that other processes, such as the production of bactericidal peptides $(32,33)$, play significant roles in airway antibacterial mechanisms. A dramatic reduction of iNOS expression and function throughout the airway epithelium, however, would severely hinder an important first-line defense mechanism and would increase the susceptibility of the airways to bacterial infections.

We have established that murine CF airway epithelium is lacking in both total NO production and in iNOS expression. Although this paper has focused on iNOS expression due to its role in immunological responses, the function and expression of both endothelial NOS and neuronal NOS will need to be explored in the future, as well as what other cell types, such as macrophages, may also exhibit this change in iNOS expression. We have also shown that the possible consequences of reduced iNOS activity in airway epithelium correlate directly to two of the least well characterized aspects of CF: sodium hyperabsorption and chronic bacterial infection. These findings suggest that NO therapy may be beneficial to CF patients and they open a new area in which to look for other related therapeutic options. Determining the mechanism of how a loss of CFTR function leads to reduced iNOS expression will likely be a key to understanding cell signaling changes that occur in $\mathrm{CF}$ and hopefully lead to more effective therapeutic interventions.

Note added in proof: Subsequent to our submission of this work, Meng et al. (Meng, Q., D.R. Springall, A.E. Bishop, K. Morgan, T.J. Evans, S. Habib, D.C. Gruentert, K.M. Gyi, M.E. Hodson, M.H. Yacoub, and J.M. Polak. 1998. Lack of inducible nitric oxide synthase in bronchial epithelium: a possible mechanism of susceptibility to infection in cystic fibrosis. J. Pathol. 184:323-331) have published that iNOS expression is reduced in CF patients and in CF cell lines, complementing the studies and supporting the results presented here.

\section{Acknowledgments}

This work was supported by National Institutes of Health grants HL50160 and DK-51878 and by a grant from the Cystic Fibrosis Foundation. 


\section{References}

1. Rommens, J.M., M.C. Iannuzzi, B. Kerem, M.L. Drumm, G. Melmer, M. Dean, R. Rozmahel, J.L. Cole, D. Kennedy, N. Hidaka, et al. 1989. Identification of the cystic fibrosis gene: chromosome walking and jumping. Science. 245 : 1059-1065.

2. Riordan, J.R., J.M. Rommens, B. Kerem, N. Alon, R. Rozmahel, Z. Grzelczak, J. Zielenski, S. Lok, N. Plavsic, J.L. Chou, et al. 1989. Identification of the cystic fibrosis gene: cloning and characterization of complementary DNA. Science. 245:1066-1073.

3. Stutts, M.J., C.M. Canessa, J.C. Olsen, M. Hamrick, J.A. Cohn, B.C. Rossier, and R.C. Boucher. 1995. CFTR as a cAMP-dependent regulator of sodium channels. Science. 269:847-850.

4. Ismailov, I.I., M.S. Awayda, B. Jovov, B.K. Berdiev, C.M. Fuller, J.R. Dedman, M.A. Kaetzel, and B.A. Benos. 1996. Regulation of epithelial sodium channel by the cystic fibrosis transmembrane conductance regulator. J. Biol. Chem. 271:4725-4732.

5. Costanzo, L.S., and E.E. Windhager. 1980. Effects of PTH, ADH, and cyclic AMP on distal tubular Ca and Na reabsorption. Am. J. Physiol. 239:F478F485.

6. Crawford, I., P.C. Maloney, P.L. Zeitlin, W.B. Guggino, S.C. Hyde, H. Turley, K.C. Gatter, A. Harris, and C.F. Higgins. 1991. Immunocytochemical localization of the cystic fibrosis gene product CFTR. Proc. Natl. Acad. Sci. USA. 88:9262-9266.

7. Moncada, S., R.M.J. Palmer, and E.A. Higgs. 1991. Nitric oxide: physiology, pathophysiology and pharmacology. Pharmacol. Rev. 43:109-142.

8. Light, D.B., E.M. Schwiebert, K.H. Karlson, and B.A. Stanton. 1989. Atrial natriuretic peptide inhibits a cation channel in renal inner medullary collecting duct cells. Science. 243:383-385.

9. Rozenweig, A., and C.E. Seidman. 1991. Atrial natriuretic factor and related peptide hormones. Annu. Rev. Biochem. 60:14636-14642.

10. Grasemann, H., E. Michler, M. Wallot, and F. Ratjen. 1997. Decreased concentration of exhaled nitric oxide (NO) in patients with cystic fibrosis. Pediatr. Pulmonol. 24:173-177.

11. Lundberg, J.O., S.L. Nordvall, E. Weitzberg, H. Kollberg, and K. Alving. 1996. Exhaled nitric oxide in paediatric asthma and cystic fibrosis. Arch. Dis. Childhood. 75:323-326.

12. Balfour-Lynn, I.M., A. Laverty, and R. Dinwiddie. 1996. Reduced upper airway nitric oxide in cystic fibrosis. Arch. Dis. Childhood. 75:319-322.

13. Dotsch, J., S. Demirakca, H.G. Terbrack, G. Hulls, W. Rascher, and P.G. Kuhl. 1996. Airway nitric oxide in asthmatic children and patients with cystic fibrosis. Eur. Resp. J. 9:2537-2540.

14. Hibbs, J.B., R.R. Taintor, Z. Vavrin, and E.M. Rachlin. 1988. Nitric oxide: a cytotoxic activated macrophage effector molecule. Biochem. Biophys. Res. Commun. 157:87-94.

15. Pheng, L.H., C. Francoeur, and M. Denis. 1995. The involvement of nitric oxide in a mouse model of adult respiratory distress syndrome. Inflammation. 19:599-610.

16. Felley-Bosco, E., S. Ambs, C.J. Lowenstein, L.K. Keefer, and C.C. Harris. 1994. Constitutive expression of inducible nitric oxide synthase in human bronchial epithelial cells induces c-fos and stimulates the cGMP pathway. Am. J. Resp. Cell Mol. Biol. 11:159-164.

17. Rosbe, K.W., J.W. Mims, J. Prazma, P. Petrusz, A. Rose, and A.F. Drake. 1996. Immunohistochemical localization of nitric oxide synthase activity in upper respiratory epithelium. Laryngoscope. 106:1075-1079.

18. Guo, F.H., H.R. DeRaeve, T.W. Rice, D.J. Stuehr, F.B.J.M. Thunnisen, and S.C. Erzurum. 1995. Continuous nitric oxide synthesis by inducible nitric oxide synthase in normal human airway epithelium in vivo. Proc. Natl. Acad. Sci. USA. 92:7809-7813.

19. Ahn, K.Y., M.G. Mohaupt, K.M. Madsen, and B.C. Kone. 1994. In situ hybridization localization of mRNA encoding inducible nitric oxide synthase in rat kidney. Am. J. Physiol. 267:F748-F757.

20. Hoffman, R.A., G. Zhang, N. Nussler, S.L. Gleixner, H.R. Ford, R.L. Simmons, and S.C. Watkins. 1997. Constitutive expression of inducible nitric oxide synthase in the mouse ileal mucosal. Am. J. Physiol. 272:G383-G392.
21. Grubb, B.R., R.N. Vick, and R.C. Boucher. 1994. Hyperabsorption of $\mathrm{Na}+$ and raised $\mathrm{Ca}(2+)$-mediated $\mathrm{Cl}$ - secretion in nasal epithelial of $\mathrm{CF}$ mice. Am. J. Physiol. 266:C1478-C1483.

22. Kelley, T.J., K. Thomas, L.J.H. Milgram, and M.L. Drumm. 1997. In vivo activation of the cystic fibrosis transmembrane conductance regulator mutant $\Delta$ F508 in murine nasal epithelium. Proc. Natl. Acad. Sci. USA. 94:2604-2608.

23. Zeiher, B.G., E. Eichwald, J. Zabner, J.J. Smith, A.P. Puga, P.B. McRay, M.R. Capecchi, M.J. Welsh, and K.R. Thomas. 1995. A mouse model for the $\Delta \mathrm{F} 508$ allele of cystic fibrosis. J. Clin. Invest. 96:2051-2064.

24. Snouwaert, J.N., K.K. Brigman, A.M. Latour, N.N. Malouf, R.C. Boucher, O. Smithies, B.H. Koller. 1992. An animal model for cystic fibrosis made by gene targeting. Science. 257:1083-1088.

25. MacMicking, J.D., C. Nathan, G. Hom, N. Chartrain, D. S. Fletcher, M. Trumbauer, K. Stevens, Q.-W. Xie, K. Sokol, N. Hutchinson, et al. 1995. Altered response to bacterial infection and endotoxic shock in mice lacking inducible nitric oxide synthase. Cell. 81:641-650.

26. Koller, B.H., H.S. Kim, A.M. Latour, K. Brigman, R.C. Boucher, P. Scambler, B. Wainwright, and O. Smithies. 1991. Toward an animal model of cystic fibrosis: targeted interruption of exon 10 of the cystic fibrosis transmembrane regulator gene in embryonic stem cells. Proc. Natl. Acad. Sci. USA. 88: 10730-10734.

27. Eckman, E., C.U. Cotton, D.M. Kube, and P.B. Davis. 1995. Dietary changes improve survival of CFTR S489X homozygous mutant mouse. Am. J. Physiol. 269:L625-L630.

28. Saito, S., K. Onozuka, H. Shinomiya, and M. Nakano. 1991. Sensitivity of bacteria to NaNO2 and to L-arginine-dependent system in murine macrophages. Microbiol. Immunol. 35:325-329.

29. Ottaviani, E., L.R. Paemen, P. Cadet, and G.B. Stefano. 1993. Evidence for nitric oxide production and utilization as a bactericidal agent by invertebrate immunocytes. Eur. J. Pharmacol. 248:319-324.

30. Schmidt, H.H.H.W., and U. Walter. 1994. NO at work. Cell. 78:919-925.

31. Gosselin, D., J. DeSanctis, M. Boule, E. Skamene, C. Matouk, and D. Radzioch. 1995. Role of tumor necrosis factor alpha in innate resistance to mouse pulmonary infection with Pseudomonas aeruginosa. Infect. Immun. 63: 3272-3278.

32. Smith, J.J., S.M. Travis, E.P. Greenberg, and M.J. Welsh. 1996. Cystic fibrosis airway epithelia fail to kill bacteria because of abnormal airway surface fluid. Cell. 85:229-236.

33. Goldman, M.J., G.M. Anderson, E.D. Stolzenberg, U.P. Kari, M. Zasloff, and J.M. Wilson. 1997. Human beta-defensin-1 is a salt-sensitive antibiotic in lung that is inactivated in cystic fibrosis. Cell. 86:553-560.

34. Barnes, P.J. 1993. Nitric oxide and airways. Eur. Resp. J. 6:163-165.

35. Persson, M.G., O. Zetterstrom, V. Agrenius, E. Ihre, and L.E. Gustafsson. 1993. Single-breath nitric oxide measurements in asthmatic patients and smokers. Lancet. 343:146-147.

36. Hamid, Q., D.R. Springall, V. Riveros-Moreno, P. Chanez, P. Howarth, A. Redington, J. Bousquet, P. Godard, S. Holgate, and J.M. Polak. 1993. Induction of nitric oxide synthase in asthma. Lancet. 342:1510-1513.

37. Kharitonov, S.A., D. Yates, R.A. Robbins, R. Logan-Sinclair, E.A Shinebourne, and P.J. Barnes. 1994. Increased nitric oxide in exhaled air of asthmatic patients. Lancet. 343:133-135.

38. Geary, C.A., M.F. Goy, and R. Boucher. 1993. Synthesis and vectorial export of cGMP in airway epithelium: expression of soluble and CNP-specific guanylate cyclases. Am. J. Physiol. 263:L598-L605.

39. Kelley, T.J., L. Al-Nakkash, and M.L. Drumm. 1997. C-type natriuretic peptide control of chloride secretion in airway epithelial cells. Am. J. Resp. Cell Mol. Biol. 16:464-470.

40. Sato, T., Y. Kamata, M. Irifune, and T. Nishikawa. 1995. Inhibition of purified $(\mathrm{Na}+, \mathrm{K}+)$-ATPase activity from porcine cerebral cortex by NO generating drugs. Brain Res. 704:177-120.

41. Roczniak, A., and K.D. Burns. 1996. Nitric oxide stimulates guanylate cyclase and regulates sodium transport in rabbit proximal tubule. Am. J. Physiol. 270:F106-F115.

42. Gupta, S., R.B. Moreland, R. Munarriz, J. Daley, I. Goldstein, and I.S. de Tejada. Br. J. Pharm. 116:2201-2206. 